\title{
SSH1 Gene
}

National Cancer Institute

\section{Source}

National Cancer Institute. SSH1 Gene. NCI Thesaurus. Code C115077.

This gene plays a role in both protein dephosphorylation and cell projection formation. 